\title{
ALLAH MENJADI MANUSIA \\ Sebuah Uraian Teologis
}

Ibelala Gea

\begin{abstract}
This article aims to explain the motive and the theological purpose why God became human, and how the apostle John explained contextually, to be understood by readers and listeners, especially as found in the prologue of the Gospel of John 1: 1-18. Results of the study is that the apostle John uses the term "Logos" to explain how the process of God became man or the Word made flesh;to remain rooted in the understanding of Judaism which by Hokmah-Yahweh namely through "Dabar Yahweh" has created the universe (Genesis 1: 1). John understood as God by His Word created the heavens and the earth in conception and mindset of Judaism. Therefore John introduces an all-divine Jesus sesubstance and equal with God, as God is equal to His Word.To explain it, John preached the existence of Jesus Christ since the pre-existence that is before the becoming of Jesus Christ became flesh, that in the beginning was the Word, the Word was with God and the Word was God, John 1: 1 (In the beginning was the Word, and the Word was God).The becoming God became man is reposition act of God to communicate with sin man absolutely, after repeated He spoke to man (Hebrews 1: 1-3).Therefore, Jesus Christ is as the fullness of God or Pleromai (John 1:16; Colossians 1:19). So based on the function and existence of Jesus Christ as the finalization of the fullness of God, Jesus Christ is the source of grace, so in Him, the grace of God acceptable not the others (John 14: 6)
\end{abstract}

Keywords: God and Human

\begin{abstract}
Abstrak
Artikel ini bertujuan untuk menjelaskan apa motif dan tujuan teologis mengapa Allah menjadi manusia, dan bagaimana cara rasul Yohanes menjelaskan secara kontekstual, hingga dapat difahami oleh para pembaca dan pendengar, khususnya sebagaimana yang dijumpai pada prolog Injil Yohanes 1:1-18. Hasil penelitian adalah bahwa rasul Yohanes menggunakan istilah "Logos" untuk menjelaskan bagaimana prosesnya Allah menjadi manusia atau Firman yang menjadi daging; dengan tetap mengakar pada pemahaman Yudaisme dimana oleh Hokmah-Yahwe yakni melalui "Dabar Yahwe" telah menciptakan alam semesta (kejadian 1:1). Yohanes memahami sebagaimana Allah oleh Firman-Nya telah menciptakan langit dan bumi dalam konsepsi dan pola pikir Yudaisme. Sebab itu Yohanes memperkenalkan ke-Illahi-an Yesus yang se-zat dan setara dengan Allah, sebagaimana Allah sama dengan Firman-Nya. Untuk menjelaskan hal itu, Yohanes memberitakan eksistensi Yesus Kristus sejak pra-eksistensi yakni sebelum kemenjadian Yesus Kristus menjadi daging, yakni pada mulanya adalah Firman, Firman itu bersamasama dengan Allah dan Firman itu adalah Allah, Yohanes 1:1 (In the begining was the Word, and the Word was God). Kemenjadian Allah menjadi manusia adalah tindakan resposisi diri Allah untuk berkomunikasi dengan manusia berdosa dan bersifat final, setelah berulang kali Dia berfirman kepada manusia (Ibrani 1:1-3). Sebab itu Yesus
\end{abstract}


Kristus adalah sebagai kepenuhan Allah atau Pleromai (Yohanes 1:16; Kolose 1:19). Maka berdasarkan fungsi dan eksistensi Yesus Kristus sebagai finalisasi kepenuhan Allah, maka Yesus Kristus menjadi sumber kasih karunia, sehingga hanya dalam Dia, kasih karunia Allah dapat diterima, bukan yang lain (Yohanes 14:6).

Kata Kunci: Allah dan Manusia.

\section{PENDAHULUAN}

Formula Allah menjadi manusia adalah sesuatu yang impossible, karena tidak masuk akal, sebab bagaimana mungkin Allah yang adalah Roh menjadi daging. Konsepsi pemikiran ini dianut oleh Gnostisme dan Hellenisme Yunani ketika Yohanes menjelaskan Allah menjadi manusia sebagaimana tertera dari prolog Injil Yohanes 1:1-18. Demikian juga pada masa kini, jangankan orang yang bukan Kristen, umat Kristen saja pun masih memandang hal itu sesuatu yang irrasional. Di kalangan para mahasiswa, khususnya yang sedang studi teologi, menurut pengamatan peneliti masih ditemukan yang belum memahami dengan benar dan baik sekaitan tema tersebut. Jika para mahasiswa sajapun masih belum memiliki pemahaman yang benar dan baik tentang tema Allah menjadi manusia sebagaimana diungkapkan dalam Alkitab, khususnya Injil Yohanes, bagaimana pula dengan warga jemaat yang adalah kaum awam terhadap teologis. Sebab itu tema ini masih relevan untuk diperbincangkan, terutama untuk memahami secara kontekstual apa sebabnya penginjil Yohanes menjelaskan konsepsi Allah menjadi manusia dengan para pendengarnya orang-orang Yahudi yang telah terkontaminasi dengan konsepsi dan pola pikir Yudaisme-Hellenisme, dan mereka yang non-Yahudi beserta konsepsi berpikir Gnostisisme dan Docetisme.

Sesungguhnya Yohanes, dia sedang menghadapi pola pikir dan konsepsi berpikir Yudaisme-Hellenistis, Gnostisisme dan Docetisisme. Maka Yohanes menggunakan situasi pola pikir dan konsepsi tersebut sebagai strategi supaya penjelasannya dapat difahami secara kontekstual. Kelihatannya Yohanes sedang menghadapi ajaran sesat dimasa itu, sehingga ia berjuang menjelaskan berita Injil sedemikian rupa supaya mudah difahami oleh orang-orang yang mendengarkan ajarannya. Hal itu didukung oleh pendapat Dave, sebagai penafsir Injil Yohanes 
1-5 yang mengatakan: "Yohanes memang mempunyai maksud yang bersifat teologis, tetapi tepatnya fakta-fakta yang dia catat tidak merugikan demi kepentingan teologinya. Teologi dan sejarah tidak berlawanan. Teologi yang benar mempunyai akar dalam sejarah yang benar. Ini penting sekali pada zaman Yohanes, karena rupanya di menghadapi suatu kecenderungan ajaran sesat". ${ }^{1}$ Maka jika diperhatikan sejarah bahwa ajaran yang berkembang dengan pesat dimasa Yohanes adalah faham Gnostisisme, mengajarkan bahwa Allah adalah berada di dunia roh karena Dia adalah suci dan tidak mungkin Dia hadir di dunia materi yang jahat dan buruk ini. Sedangkan manusia yang berada di dunia materi tidak gampang memasuki dunia roh, harus memiliki sejumlah kemampuan seperti memiliki pengetahuan yang tinggi, bukan pengetahuan intelektual melainkan pengetahuan yang bersifat misteri dengan yang illahi serta memperoleh percikan illahi. Dari keyakinan Gnostisisme tersebut, Yohanes mau meyakinkan bahwa Allah yang maha suci itu telah menjadi daging atau manusia di dalam pribadi Yesus Kristus dengan menjelaskannya melalui konsepsi dan pola pikir Hellenisme dan Gnostisisme seperti Logos. Injil Yohanes ditulis oleh Yohanes anak Zebedeus, salah seorang murid yang paling dekat dengan Yesus diantara keduabelas muridNya dan termasuk seorang dari antara para rasul yang memimpin gereja perdana. ${ }^{2}$ Dimana Injil Yonanes menurut keterangan para bapa gereja menyatakan "Kitab Injil ditulis oleh Rasul Yohanes pada akhir kehidupan yang panjang dan kebanyakan para ahli mengatakan bahwa waktu penulisan itu antara tahun 70 dan 100 Masehi. $^{3}$

Injil Yohanes memiliki ciri khas tersendiri, baik dari segi bahasa, pola pikir maupun pendekatan atau strategi yang digunakan untuk menjelaskan tentang Yesus Kristus sebagai Anak Allah, Juruselamat dunia bahkan sebagai Kurios atau Tuhan. Latar belakang para pembaca dan penerima Injil Yohanes adalah orangorang Yahudi dan non-Yahudi. Orang Yahudi yang dimaksud sebagai alamat yang dituju dalam penulisan Injil Yohanes adalah orang-orang Yahudi yang pola pikir mereka telah terkontaminasi dengan budaya Yunani-Hellenisme.

Yohanes menjelaskan Yesus Kristus kepada mereka bertitik-tolak dari pola pikir dan pemahaman Hellenisme, walaupun tidak mengabaikan akar 
keyakinan mereka dari budaya Yudaisme, sebab Yesus Kristus tidak akan dapat difahami dan dimengerti dengan baik jika dilepaskan dari akar keyakinan Yudaisme. Karena Yesus dinubuatkan, lahir, besar, berkarya melayani, melaksanakan misi-Nya sebagai Mesianis di dalam konteks Yudaisme. Sebab itu Yohanes memperkenalkan Yesus Kristus dengan seperangkat akar keyakinan Yudaisme tentang Allah tetapi dengan memakai bahasa dan pola pikir Hellenisme, yang pasti pola pikir filsafat Yunani sangat dominan di dalamnya.

Pemberitaan Injil Yohanes tentang Yesus Kristus berbeda dengan Injil Sinoptis yang memberitakan Yesus Kristus dimulai sejak kelahiran-Nya, tetapi Yohanes jauh sebelum peristiwa kelahiran, dikenal dengan istilah pra-eksistensi. Penjelasan Yohanes dimulai dengan sebelum kemenjadian Yesus menjadi manusia. Sebaliknya Injil Sinoptis tidak menjelaskan Yesus dari aspek praeksistensi. Melainkan, Injil Matius dan Lukas hanya memberitakan kelahiran Yesus Kristus dengan batas terdekat dengan pra-eksistensi, yakni ketika kelahiran Yesus diberitakan melalui Roh Kudus yang menaungi Maria dengan membuahi rahimnya (Matius 1:20, Lukas 1:35). Sebab itu dapat dimengerti bahwa penginjl Matius dan Lukas memberi penjelasan bahwa kemenjadian Yesus sebagai manusia tidak hanya dimulai di kandang domba di Betlehem-Efrata melainkan dimulai sejak di rahim atau kandungan Maria (Matius 1:19).

Karena itu menjadi pembelajaran bagi para pembaca bahwa Yesus Kristus menjadi manusia bukan dimulai di kandang domba sebagaimana sering diungkapkan pada liturgi dan atau pada renungan saat-saat hari natal, melainkan dimulai sejak dari rahim Maria, sebab di situlah Yesus menjadi manusia. Karena itu penderitaan Yesus sudah dimulai sejak dari dalam kandungan Maria. Penginjil Markus sama sekali tidak mewartakan tentang kelahiran, apalagi masalah praeksistensi, justeru yang diberitakan Markus adalah soal permulaan Injil Yesus Kristus (Markus 1:1). Hal ini juga menjadi pembeda dan ciri khas Injil Markus dari pada Injil lainnya. Markus hendak mengatakan bahwa sudah tiba saatnya tergenapi nubuat Nabi Yesaya dimana Yesus sebagai Mesias hadir sebagai penggenapan nubuatan Perjanjian Lama yang solid dengan manusia berdosa. Sebab itu baptisan Yesus bukan karena Ia berdosa, melainkan menyamakan diri- 
Nya dengan orang berdosa. Pengungkapan pemberitaan pra-eksistensi Yesus, justru disampaikan oleh Rasul Paulus dengan mengatakan bahwa Yesus adalah Plerauma atau kepenuhan Allah (Kolose 1:15-20). Sebab itu sering dikatakan ada kesamaan teologia Rasul Yohanes dengan Rasul Paulus.

Penjelasan Rasul Yohanes tentang pra-eksistensi Yesus dalam Injilnya adalah dilatarbelakangi dengan konsepsi dan pola berpikir hokmah-hikmatYudaisme. Literatur menyatakan bahwa eksistensi dan fungsi hokmah-Jahwe atau Hikmat Allah adalah sama dengan Dabar-Yahwe atau Firman Allah. Dimana istilah 'bara' dalam bahasa Ibrani senantiasa menunjuk kepada Allah, yang mana Allah menciptakan langit dan bumi - Kejadian 1:1, bermakna menciptakan sesuatu dari yang tidak ada menjadi ada. Sesuatu yang baru sama sekali, tanpa bahan dasar, dan dapat mengandung pengertian kreatif, maka kata bara dalam bahasa latin disebut: 'Creatio Ex Nihillo'. Namun dalam penciptaan mengenai manusia dipakai kata 'yasar' artinya “membentuk" dan "mencetak" dari bahan yang telah tersedia. Manusia dibentuk Allah dengan tangan-Nya sendiri dari bahan debu tanah (Kejadian 2:7). Dimana manusia menjadi ujud dan rupa yang spesifik yang berbeda dengan ciptaan yang lain. Istilah 'debu' dalam bahasa Ibrani 'apar' dan 'tanah' disebut 'adama'. Sedangkan Allah dalam menciptakan manusia dipakai istilah ' $Y H W H$ ' yang berati TUHAN. Maka selengkapnya adalah, TUHAN ALLAH membentuk manusia dari debu tanah dan menghembuskan nafas hidup kedalamnya, demikianlah manusia itu menjadi makhluk yang hidup (Kejadian 2:7).

Jika Hokmah Yahwe atau Hikmat Allah adalah sama dengan Dabar Yahwe yang adalah Firman Allah, Ia berpribadi, bekerja di luar diri Allah atas perintah Allah, namun Hokmah Yahwe atau Dabar Yahwe bukanlah oknum yang lain dari Allah. Dia adalah Allah sendiri yang dapat menjelma dan hadir di tengah-tengah manusia. Dabar Yahwe atau Hokmah Yahwe itu tergambarkan pada Amsal 8:12, 22-36, yaitu: Aku, hikmat tinggal bersama-sama dengan kecerdasan, dan aku mendapat pengetahuan dan kebijaksanaan. Tuhan telah menciptakan aku sebagai permulaan pekerjaan-Nya, sebagai perbuatan-Nya yang pertama-tama dahulu kala. Sudah pada zaman purbakala aku dibentuk, pada mula pertama, sebelum 
bumi ada........dst. Hokmah Yahwe ini diterima oleh Raja Sulaeman Amsal 18:15 dan diaplikasikan dalam kehidupannya sehari-hari sebagai Raja.

Kemudian di dalam budaya Hellenistis dan konsepsi serta pola pikir Gnostisisme ada pemahaman tentang logos. Di mana difahami bahwa logos adalah bersifat Maha Ada atau The Ultimate Being yang selalu bergerak, dimana dalam pergerakannya itu logos mencipta, sehingga ia menjadi asal mula sesuatu. Dalam pergerakannya Logos melakukan 'emanasi' yaitu memercikan diri sehingga timbullah logos kecil yang eksistensinya dan fungsinya berada di bawah logos besar. Itulah sebabnya ketika Yohanes memperkenalkan Yesus Kristus kepada pendengarnya yaitu orang Yahudi dan non-Yahudi yang telah terkontaminasi oleh konsepsi dan pola pikir Hellenistis dan Gnostisisme maka pemahaman mereka tentang siapa Yesus Kristus adalah kurang lebih sama dengan konsepsi logos dalam pemahaman gnostisisme. Pada zaman Yohanes, gnostisisme merupakan gerakan keagamaan yang sangat berpengaruh.

Konsepsi dan pola pikir gnostisisme didasarkan atas kepercayaan bahwa ada dua dunia, yaitu, pertama: dunia roh tempat Allah berada adalah dunia yang suci; kedua: dunia materi tempat manusia berada adalah tempat yang jahat dan buruk. Para penganut gnostik berpandangan bahwa Allah yang Maha Suci itu tidak berhubungan dengan dunia materi. Sebab itu jika manusia ingin bahagia harus berupaya meloloskan diri dari dunia yang jahat dan buruk ini, dimana satu caranya adalah dengan bertapa atau askese. Para pengikut gnostisisme memahami bahwa kesempatan untuk meloloskan diri dari dunia materi adalah pada waktu kematian yaitu dimana roh meninggalkan raga. Namun diyakini bahwa tidak semua manusia bisa lolos memasuki dunia roh, kecuali telah memiliki percikan illahi, jika tidak maka akan kembali ke dunia materi menjalani kehidupan jasmani yang tidak bermakna. Sebab itu gnostik mengajarkan manusia harus memiliki pengetahuan intelektualitas, tetapi pengetahuan, pengalaman secara mistik yang langsung denga Allah yang Maha Suci. Artinya, pemahaman para pendengar Yohanes memiliki konsepsi dan pola pikir bahwa ke-Illahi-an Yesus ditempatkan berada di bawah derajat ke-Illahi-an Allah. Maka misi Yohanes adalah bertugas menjelaskan bahwa ke-Illahi-an Yesus tidak sama dengan konsepsi logos 
gnostisisme. Yohanes menjelaskan ke-Illahian Yesus bertolak dari konsepsi Hokmah Yahwe dan Dabar Yahwe Yudaisme. Akan tetapi supaya formula Kristologi itu kontekstual, maka Yohanes menjelaskannya dengan menggunakan konsepsi, bahasa dan pola pikir gnostisisme, dimana untuk kata Hokmah Yahwe diganti dengan kata Logos yang berarti The Word of God, sama dengan Kalam atau Firman Allah, maka lahirlah kalimat: Pada mulanya adalah Firman, Firman itu bersama-sama dengan Allah dan Firman itu adalah Allah, Firman itu telah menjadi daging (LAI menterjemahkannya: daging = manusia). Yohanes 1:1: Ev

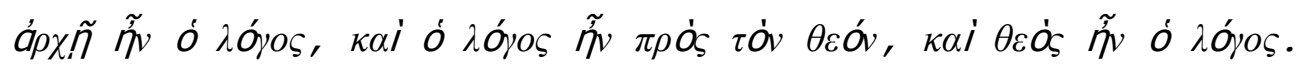

Yohanes menulis Injilnya dengan tujuan terlihat pada Yohanes 20:30-31, bahwa: "Memang masih banyak tanda lain yang dibuat Yesus di depan mata murid-murid-Nya, yang tidak tercatat dalam kitab ini, tetapi semua yang tercantum di sini telah dicatat, supaya kamu percaya, bahwa Yesuslah Mesias, Anak Allah, dan supaya kamu oleh imanmu memperoleh hidup dalam namaNya". Artinya Yohanes hendak memberitakan bahwa kebahagiaan yaitu hidup kelal bukan pada kepercayaan sebagaimana faham gnostisisme, melainkan hanya dalam nama Yesus, Dialah Mesias yang dinanti-nantikan bangsa Yahudi. Hal ini didukung oleh Leo Morris. ${ }^{4}$

Selanjutnya kata daging adalah sarks $(\sigma \alpha \rho \xi)$ yang berarti bersifat duniawi, fana, tetapi dapat juga diartikan manusia. Oleh sebab itu dapat dikatakan bahwa Firman yang telah menjadi daging adalah sama dengan Firman yang telah mendunia atau membumi, karena telah menjadi manusia. Penjelasan Yohanes bahwa Firman atau Allah menjadi manusia sangat bertentangan dengan kepercayaan kaum Gnostisisme dan Docetisme. Allah menjadi manusia itu berarti Allah menyatakan diri-Nya, yang selama ini dalam kepercayaan Gnostisisme dan Docetisme, Allah hanya bertakhta atau berada di singgasana sorga. Tetapi sekarang lebih hadir di tengah-tengah manusia (Yohanes 1:14,18). Yohanes hendak mengatakan bahwa Firman itu adalah Allah dan Allah itu adalah Yesus Kristus yang adalah Juruselamat manusia adalah sama dengan Allah. Agaknya pemikiran para pendengar Yohanes sudah familiar dengan filsafat Phythagoras yang dapat dikatakan demikian: "Jika a sama dengan b, dan b sama dengan c, 
maka dipastikan bahwa a sama dengan c". Pola pikir ini kelihatannya Yohanes gunakan sebagai metodenya untuk menjelaskan kesamaan hakekat Firman Allah dengan Yesus Kristus, tujuan penggunaan pendekatan ini oleh Yohanes adalah supaya penjelasan Kristologinya kontekstual.

\section{TUJUAN PENELITIAN}

Tujuan penelitian ini adalah untuk menjelaskan makna, motif dan tujuan teologis Allah menjadi manusia, dan bagaimana cara Yohanes menguraikan secara kontekstualitas, hingga dapat difahami dan diterima oleh para pendengar berita Injil, khususnya prolog Yohanes 1:1-18.

\section{METODE PENELITIAN}

Metode penelitian yang digunakan adalah pendekatan kajian pustaka (Library Research). Dengan meneliti makna dan tujuan, motif teologis Allah menjadi manusia menurut versi konsepsi Injil Yohanes, serta meneliti buku-buku yang berhubungan dengan Injl Yohanes.

\section{ALLAH MENJADI MANUSIA}

Setelah memaparkan latar belakang pada tulisan ini dan pola pikir yang terdapat pada prolog Injil Yohanes 1:1-18 sebagaimana telah dijelaskan pada pendahuluan tulisan ini. Maka selanjutnya akan mengungkapkan apa tujuan dan motif teologis mengapa Allah menjadi manusia.

Secara fakta apa tujuan dan motif Allah menjadi manusia, peneliti mengungkapkan bahwa ada 2 (dua) garis besar tujuan dan motif Allah menjadi manusia yaitu:

\section{Tindakan Allah yang selalu mereposisi diri dalam berkomunikasi dengan manusia yang berdosa.}


Istilah Allah mereposisi diri, Peneliti mendasari pemikiran dari apa yang diungkapkan oleh penulis surat Ibrani 1:1-2, yang berbunyi: "Setelah pada zaman dahulu Allah berulangkali dan dalam pelbagai cara berbicara kepada nenek moyang kita dengan perantaraan Nabi-nabi, maka pada zaman akhir ini Ia telah berbicara kepada kita dengan perantaraan Anak-Nya, yang telah Ia tetapkan sebagai yang berhak menerima segala yang ada. Oleh Dia, Allah telah menjadikan alam semesta”. Terjemahan Holy Bible, New KING James Version (NKJV) seperti berikut: “God, who at various times an in various ways spoke ini time past to the fathers by the Prophets, has in these last days spoker to us by His Son, whom He has appointed heir of all things, through whom also He made the worlds".

Pertanyaan yang mesti diajukan adalah mengapa Allah berulangkali dan dalam berbagai cara berbicara atau berkomunikasi dengan manusia? Ternyata bahwa manusia sulit menangkap, mengerti dan memahami tujuan, motif dan kehendak Allah. Kendatipun Allah telah berfirman secara verbal, tetapi Firman yang disampaikan secara lisan itu tidak dimengerti oleh manusia. Kemudian Allah berfirman secara tertulis, hal itu terlihat pada Firman-Nya (Taurat), namun Firman itu juga tidak dapat dimengerti, apalagi dilakukan dengan benar oleh manusia. Allah kemudian berfirman melalui perantaraan, Idomatum Verbum Dei, melalui hakim-hakim, raja-raja, nabi-nabi bahkan melalui peristiwa. Akan tetapi manusia juga tidak mengerti dan tidak memahami tujuan dan motif teologis mengapa Allah yang adalah Firman mau menjadi manusia. Akhirnya Allah berfirman kepada manusia dengan cara berinkarnasi, Allah menjadi daging yaitu dalam pribadi Yesus Kristus.

Inkarnasi dari bahasa Latin yakni incarnatio, dimana in artinya "masuk ke dalam" dan carno atau carnis artinya "daging". Dengan demikian inkarnasi adalah tindakan Yesus Kristus masuk ke dalam daging, Ia benar-benar manusia, lahir dari seorang perempuan (Galatia 4:4), artinya Ia sungguh-sungguh manusia, dilahirkan sebagaimana manusia dilahirkan dari rahim ibunya. Itulah sebabnya dalam pengakuan iman rasuli dikatakan bahwa Ia lahir dari anak dara Maria. 
Berkaitan dengan Allah menjadi manusia dalam Yesus Kristus, maka Dave Hagelberg, berpendapat: Dengan kata 'dalam berbagai cara' penulis surat Ibrani bermaksud menyatakan bahwa dahulu Firman Allah disampaikan melalui mimpi, penglihatan, beban para nabi, sejarah yang ditulis, berita dari malaikat dan sebagainya. Tetapi bagaimana jika semuanya ini dibandingkan dengan pernyataan Tuhan Yesus, Firman Allah yang hidup dan pengajaran-Nya? Memang semua cara yang digunakan Allah tersebut mulia, namun tidak sebanding dengan pernyataan Allah sendiri, yaitu Firman yang hidup, Yesus Kristus, Tuhan kita. ${ }^{5}$

Penyataan Allah, dengan berkomunikasi kepada manusia melalui cara yang tidak ada tandingannya yaitu reinkarnasi atau menjelma menjadi daging atau manusia dalam Yesus Kristus. Penekanan Yohanes yang hendak mendeskripsikan pribadi Kristus, ditegaskan oleh J. Wesley, bahwa: "Semua orang mengakui bahwa Yohanes mempertahankan ke-Tuhan-an Kristus. Ia berkata, 'Firman itu adalah Allah' dan menyebut Yesus 'Anak Tunggal Bapa'. Orang-orang Farisi telah membenci Yesus karena Ia mengatakan diri-Nya 'Anak Tunggal Bapa', Yohanes yakin bahwa Yesus dari Nazaret adalah Anak Allah. Maksud keempat Injil ialah menyatakan bahwa Yesus Kristus adalah 'Allah-Manusia', Immanuel, Allah beserta kita, Juruselamat manusia". ${ }^{6}$ Sebab itu keyakinan Kristen, bahwa: "Firman Allah yang sejati adalah Tuhan Yesus Kristus, sebab Ialah Firman Allah yang telah menjadi manusia. ${ }^{7}$ Yohanes mengatakan bahwa: "Logos ada pada mulanya, dan bahwa Ia bersama-sama dengan Allah dan Ia adalah Allah. ${ }^{8}$

Dalam setiap cara dan strategi Allah berfirman kepada manusia, Ia selalu mereposisi diri, itu menunjukkan bahwa Allah berfirman bukan hanya dari singgasana keIllahian-Nya saja yang jauh di tempat yang maha tinggi. Akan tetapi Allah juga turun ke bumi, menyatu dengan keberadaan hidup manusia, baik kepada seseorang sebagai pribadi atau sebagai representasi umat, maupun kepada umat-Nya secara kolektif.

\section{Allah mengambil rupa manusia untuk memperbaiki citra manusia}


Pemahaman Allah mengambil rupa manusia didasarkan pada Kristologi Kenotic Paulus, yakni bahwa Allah mengosongkan diri mengambil rupa seorang hamba dan menjadi sama dengan manusia (Filipi 2:5-8). Ketika Adam diciptakan, ia diciptakan segambar dengan Allah atau Imago Dei (Kejadian 1:26-27). Akan tetapi dengan pelanggarannya dan kejatuhannya ke dalam dosa, Adam manusia yang pertama itu, telah gagal sebagai Imago Dei. Rupa Allah di dalam diri manusia telah rusak oleh perbuatan dosanya. Berhubung oleh karena yang menciptakan manusia itu adalah Allah, maka Allah sendirilah yang menjadi pemilik manusia. Sebab itu adalah kepentingan Allah sendiri untuk memperbaiki atau merestorasi dan merehabilitasi keberadaan manusia. Tujuannya agar manusia tidak berada di bawah bayang-bayang maut atau hukuman atas dosa. Allah sangat berkehendak supaya citra manusia, sebagai ciptaan dan kepunyaan-Nya kembali utuh. Melalui tindakan itu Allah menunjukkan diri bukan hanya sekedar pencipta, creator, melainkan sekaligus juga sebagai pemelihara atau providentia Dei dan sebagai Soter atau penyelamat.

Oleh karena manusia telah gagal sebagai Imago Dei, maka Allah di dalam diri Yesus Kristus mengambil rupa manusia, sehingga ia segambar dengan manusia atau Imago-humanis dan menjadi manusia. Karena itu dari pihak Allah, Yesus adalah diri-Nya sebagai Imago-humanis (Filipi 2:7), sedangkan dari pihak manusia, Yesus adalah Imago Dei (Filipi 2:6; Kolose 1:15) yang benar dan sempurna, dimana Yesus kemudian diposisikan sebagai Adam kedua. Maka untuk mengetahui dan memahami keutamaan-Nya, Ia pun disebut sebagai atau dibandingkan dengan Adam yang pertama (Roma 5:14; 1 Korintus 15:21, 22 45).

Sekarang dapat dikatakan bahwa baik tindakan, tujuan dan motif Allah mereposisi diri maupun mengambil rupa manusia adalah sama-sama mengandung makna teologis yakni Allah menunjukkan solidaritas dan keberpihakan-Nya kepada manusia yang menderita akibat keberdosaan itu. Sesungguhnya tindakan solidaritas dan keberpihakan Allah itu telah dimulai sejak manusia jatuh kedalam dosa. Akan tetapi solidaritas dan keberpihakan tersebut terlaksana secara 
sempurna di dalam Yesus Kristus yang lahir ke dunia, mengalami penderitaan di kayu salib, mati dan bangkit untuk keselamatan manusia. Dengan demikian motif dan tujuan "Allah menjadi manusia" adalah karena kasih-Nya, supaya manusia dan seluruh dunia selamat (Yohanes 3:16).

Terkait dengan konsepsi dan keyakinan bahwa Kristus adalah Allah yang telah menjadi manusia, namun berbagai pandangan spekulatif yang menyangkal hal itu, terutama dari pihak yang tidak mengakui bahwa Yesus adalah Allah. Dengan mengatakan bahwa yang menjadi daging bukanlah Allah, melainkan hanyalah Firman-Nya, dan Firman-Nya itu adalah Yesus, oleh sebab itu Yesus tidaklah identik atau sama dengan Allah. Pemahaman ini berasumsi bahwa Firman Allah bukan zat atau dhat Allah, melainkan hanyalah satu dari sifat Allah. Pemaham seperti ini tidak dikenal dalam kitab suci atau Alkitab. Alkitab dan tradisi Yudaisme mengajarkan bahwa memang Allah memiliki Firman seperti Dia juga memiliki Roh, sehingga disebut Firman Allah atau Roh Allah. Akan tetapi Firman Allah atau Roh Allah bukanlah pribadi lain dari Allah dan bukan pula sifat dari Allah. Firman itu zat (dhat) Allah dan Allah sendiri, Roh itu adalah zat (dhat) Allah dan Allah sendiri juga (Yohanes 4:24). Sebab itu, jika dikatakan Firman telah menjadi daging, itu berarti sama dengan Allah menjadi daging.

Masalah lain yang sering dilontarkan oleh para pemikir spekulatif adalah bahwa jika Allah telah menjadi manusia, bukankah hal itu terjadi selama umur Yesus 33 Tahun di bumi ini, Allah menjadi manusia? Dan seiring dengan itu, berarti pula bahwa Allah tidak menempati singgasana-Nya di surga? Demikian juga ketika Yesus mati, maka bukankah itu sama dengan Allah juga sudah mati? Logika dan rasio manusia belaka yang digunakan oleh kelompok-kelompok tertentu guna menruntuhkan keyakinan Kristen.

Perlu dihayati bahwa iman Kristen tidak selamanya berdasarkan rasio dan logika melulu, bahwa adakalanya rasio dan logika sulit digunakan untuk memahami dan menerima karya dan perbuatan Allah yang maha kuasa itu. Rasio dan logika manusia sangat terbatas sedangkan hikmat Allah tidak terbatas, bahkan melampaui rasio dan logika manusia. Itulah sebabnya bagi manusia selalu ada yang mustahil, sedangkan bagi Allah tidak ada yang mustahil. Oleh sebab itu 
dalam teologi Kristen dikenal pemahaman bahwa ada 3 (tiga) sifat kehadiran Allah, yaitu:

a. Transenden, yakni maha hadir atas segala-galanya.

b. Immanen, yakni dekat dan melekat dengan kehidupan manusia

c. Omnipresent, yakni hadir di mana-mana pada tempat yang berbeda tetapi pada waktu yang sama. Dengan demikian sekalipun Allah menjadi manusia didalam Yesus Kristus, itu bukan berarti Allah tidak berada di sorga, dan sekalipun Yesus pernah mati, itu bukan berarti Allah telah mati, sebab Allah itu Omnipresent dan bagi dia tidak ada yang mustahil,

\section{HASIL PENELITIAN}

Untuk menjelaskan hasil penelitian pada penulisan artikel ini, ditemukan hasil setelah menelusuri apa motif dan tujuan teologis Allah menjadi manusia menurut versi konsepsi Injil Yohanes dan elaborasi dengan berbagai sumber literatur yang relevan, maka hasilnya adalah sebagai berikut:

1. Rasul Yohanes sengaja menggunakan istilah 'Logos' untuk menjelaskan: Pada mulanya adalah Firman, Firman itu bersama-sama dengan Allah dan Firman itu adalah Allah, karena pendengar atau penerima Injilnya adalah orang-orang Yahudi yang ada di luar Palestina dan juga orang-orang yang non-Yahudi yakni orang Yunani yang telah menjadi Kristen. Akan tetapi pola pikir mereka telah dipengaruhi oleh budaya dan filsafat Yunani Hellenisme beserta ajaran Gnostisisme. Maka pemberitaan Injil Yohanes mengenai tema Firman telah menjadi manusia dan atau atau Allah menjadi manusia agar lebih kontekstual, maka Yohanes menjelaskan tema tersebut sesuai dengan pola pikir dan pemahaman yang dapat diterima pada masa itu. Salah seorang Filsuf Yunani bernama Phytagoras, dikenal sebagai ahli matematika yang merumuskan hukum Geometri dan dikenal dengan Dalih Phytagoras, yang menjelaskan bahwa dalam segitiga siku-siku jumlah kuadrat dari sisi terpanjang sama atau sebanding dengan jumlah kuadrat dari sisi-sisi lainnya. Filsafat Phytagoras yang alur pikirannya dapat dianalogikan bahwa: jika a sama dengan $b$, dan b sama dengan c, maka a 
pasti sama dengan c. Maka ketika Yohanes menjelaskan 'pada mulanya adalah Firman, Firman itu bersama-sama dengan Allah dan Firman itu adalah Allah, dan Firman itu telah menjadi manusia (daging)', maka penjelasan itu adalah kontekstual, karena familiar dengan para pendengarnya.

2. Yohanes sesungguhnya memahami bagaimana Allah yang menciptakan langit dan bumi dalam konsepsi pola pikir Yudaisme sebagaimana dijumpai pada Kejadian 1:1, Pada mulanya Allah menciptakan langit dan bumi atau In the begining God created the heaven and the earth. Di mana melalui hikmat, Allah dengan menciptakan langit dan bumi. Yohanes pun memperkenalkan keIllahian Yesus Kristus yang setara dengan Allah, itulah sebabnya dia memulai penjelasan dalam Injilnya dengan menjelaskan keberadaan Yesus sejak pra-eksistensi. Hal itu terjadi tidak lain dilatarbelakangi oleh konsepsi dan pola pikir hokmah-hikmah Allah dalam konsepsi Yudaisme. Di mana hikmat Allah adalah sama dengan 'Dabar' Yahwe atau Firman Allah, yang mana Allah menciptakan langit dan bumi dalam kejadian 1:1 yang bermakna menciptakan alam semesta dari yang tidak ada menjadi ada atau Creatio Ex-Nihillo.

3. Nampaknya ada persamaan konsepsi teologis rasul Yohanes dengan rasul Paulus dalam menjelaskan misi Mesianis Yesus Kristus, di mana keduanya mengakui bahwa Kristus adalah kepenuhan Allah (Yohanes 1:16; Kolose 1:19). Kemudian berdasarkan fungsi dan eksistensi Yesus sebagai kepenuhan Allah, maka Kristus menjadi sumber kasih karunia, sehingga dari pada-Nyalah kasih karunia Allah diterima. Sebab itu kasih karunia dan keselamatan dunia hanya dapat diterima dari Yesus Kristus (Yohanes 14:6). Perealisasian kasih karunia dan keselamatan itu dinyatakan pada peristiwa Firman menjadi manusia dalam Yesus Kristus. Oleh sebab itu, inti pokok semua Kristologi dijelaskan oleh Yohanes sejak pra-eksistensi, kelahiran, kehidupan, kematian dan kebangkitan Yesus Kristus. 
Dari penjelasan ini menginspirasi para teolog merumuskan ulang pesan teologi sebagaimana dijumpai dalam Alkitab untuk mewartakan pada masa kini secara membumi dan itulah yang dikenal dengan istilah Teologi Kontekstual, dengan tujuan agar para pendengar lebih mudah memahami dan menerimanya.

\section{PENUTUP}

Melalui hasil penelitian artikel ini, perlu disampaikan pesan teologis atau refleksi teologis, yakni:

a. Allah sangat gigih berjuang, berusaha untuk menyelamatkan manusia dari kejatuhan dalam dosa. Kegigihan dan perjuangan selalu ditandai dengan kerelaan, kesetiaan dan pengorbanan. Hal itu telah dilakukan oleh Allah ketika Dia berinkarnasi dalam pribadi Yesus Kristus. Perbuatan Allah itu berpuncak pada kelahiran, kehidupan, kematian dan kebangkitan Yesus Kristus, dan tindakan itu diungkapkan dalam satu kata yakni "menebus", Allah telah menebus manusia dari perbuatan dosa dan telah dibayar lunas dengan harga yang sangat mahal (1 Korintus 6:20).

b. Manusia yang telah menerima kasih karunia keselamatan itu, apa responnya, dia bersyukur, bersukacita, memuliakan Allah melalui seluruh aktivitas kehidupan. Hal ini menjadi sentral, mengapa orang Kristen merayakan natal, karena peristiwa natal adalah peristiwa Illahi, di mana Allah solider, berpihak kepada manusia berdosa, yang tertindas dan menderita. Allah tidak memperhitungkan kesalahan manusia. Kasih karunia keselamatan diberikan kepada siapapun baik Yahudi maupun non-Yahudi; golongan menengah ke atas atau golongan menengah ke bawah; golongan cendekiawan atau orang yang tidak berpendidikan sekalipun; masyarakat biasa, papa, hina dan jelata; semua mendapat kasih karunia keselamatan dari Yesus Kristus. Sebab itu, segala hal-hal yang berhubungan dengan kebiasaan, ibadah, ritus atau untuk mempertahankan dan meraih reputasi sosial sama sekali tidak menjadi pertimbangan di dalam Misi Mesianis Yesus Kristus. Kasih karunia dan keselamatan 
diberikan semata-mata hanya berdasarkan belas kasihan. Sebab itu perayaan natal dilakukan seiring dengan motif dan tujuan teologis dari Misi Mesianis yang diperbuat oleh Allah, direalisasikan pada pelayanan pendidikan, pembelajaran, perbuatan dan pengorbanan.

\section{Endnote :}

\footnotetext{
${ }^{1}$ Dave Hagelberg, Tafsiran Injil Yohanes Pasal 1-5, (Yogyakarta: Yayasan Andi), hlm.7-8

${ }^{2}$ Bruce Milne, Yohanes - Seri Pemahaman dan Penerapan Amanat Agung Alkitab Masa Kini, (Jakarta: Yayasan Komunikasi Bina Kasih, 1993), hlm.16-18

3 John Drane, Memahami Perjanjian Baru, (Jakarta: PT. BPK Gunung Mulia, 2006), hlm.227

${ }^{4}$ Leo Morris, The Gospel According to John, (WMB Erdmans Publishing Co: Grand Rapida Michigan, 1971), hlm. 8-15

${ }^{5}$ Dave Hagelberg, Tafsiran Ibrani dari Bahasa Yunani, (Bandung: Kalam Hidup, 2003), hlm.8

${ }^{6}$ J. Wesley Brill, Tafsiran Injil Yohanes, (Bandung: Kalam Hidup, 1976), hlm.16

${ }^{7}$ Harun Hadiwijono, Inilah Sahadatku, (Jakarta: BPK Gunung Mulia, 2001), hlm.20

${ }^{8}$ Leon Morris, Teologi Perjanjian Baru,(Jawa Timur: Yayasan Penerbit Gandum Mas, 1996), hlm.314
}

\section{DAFTAR PUSTAKA}

ALKITAB: 2012. Lembaga Alkitab Indonesia. Jakarta.

Brill. Wesley J. 1976. Tafsiran Injil Yohanes. Bandung: Kalam Hidup.

Drane. John, 2006. Memahami Perjanjian Baru. Jakarta: PT. BPK Gunung Mulia.

Guthrie. Donald, 1990. Dalam Tafsiran Alkitab Masa Kini. Jakarta: Yayasan Komunikasi Bina Kasih.

Hadiwijono. Harun, 2001. Inilah Sahadatku. Jakarta: BPK Gunung Mulia.

Hagelberg. Dave, 1999. Tafsiran Injil Yohanes Pasal 1-5. Yogyakarta: Andi.

Hagelberg. Dave, 2003. Tafsiran Ibrani dari Bahasa Yunani. Bandung: Kalam Hidup.

HOLY BIBLE, New King James Version, 2012. Lembaga Alkitab Indonesia, Jakarta.

Milne. Bruce, 1993. Yohanes - Seri Pemahaman dan Penerapan Amanat Agung Alkitab Masa Kini. Jakarta: Yayasan Komunikasi Bina Kasih.

Morris. Leo, 1971. The Gospel According to John. Grand Rapids Michigan: WMB Erdmans Publishing Co.

Morris. Leo, 1996. Teologi Perjanjian Baru. Jawa Timur: Yayasan Penerbit Gandum Mas. 